\title{
Transgenerational epigenetic inheritance: More questions than answers
}

\author{
Lucia Daxinger and Emma Whitelaw ${ }^{1}$ \\ Epigenetics Laboratory, Queensland Institute of Medical Research, Herston, Brisbane, Queensland 4006, Australia
}

\begin{abstract}
Epigenetic modifications are widely accepted as playing a critical role in the regulation of gene expression and thereby contributing to the determination of the phenotype of multicellular organisms. In general, these marks are cleared and reestablished each generation, but there have been reports in a number of model organisms that at some loci in the genome this clearing is incomplete. This phenomenon is referred to as transgenerational epigenetic inheritance. Moreover, recent evidence shows that the environment can stably influence the establishment of the epigenome. Together, these findings suggest that an environmental event in one generation could affect the phenotype in subsequent generations, and these somewhat Lamarckian ideas are stimulating interest from a broad spectrum of biologists, from ecologists to health workers.
\end{abstract}

Epigenetics became an established discipline in the 1970s and 1980 s as a result of work carried out by geneticists using model organisms such as Drosophila (Henikoff 1990). Originally, this research area aimed to understand those instances in which stable changes in genome function could not be explained by changes in DNA sequence. This definition suited Waddington's original purpose, i.e., to explain how a multicellular organism could develop from one genome (Waddington 1942). More recently, with increasing knowledge of the underlying molecular mechanisms, the field has taken on a more biochemical flavor (Bird 2007; Kouzarides 2007). Constant progress is being made in the identification of epigenetic marks, i.e., the molecular marks to the chromosome that influence genome function, and while DNA methylation remains the most extensively studied, the importance of histone modifications as well as the contribution of RNA has become increasingly clear.

There has always been much interest in the idea that some epigenetic marks can be inherited across generations. However, despite the fact that these marks are considered relatively stable during development (i.e., transmissible across mitosis), in theory they must undergo reprogramming in primordial germ cells (PGCs) and in the zygote to ensure the totipotency of cells of the early embryo, enabling them to differentiate down any pathway. For transgenerational epigenetic inheritance to occur at a particular locus, this reprogramming must be bypassed (Hadchouel et al. 1987; Roemer et al. 1997; Morgan et al. 1999). Recent reports that the establishment of epigenetic states can be altered by the environment, combined with the idea that epigenetic states can be inherited across generations, has resurrected an interest from the scientific community in Lamarckism. Here, we will highlight recent developments in our understanding of transgenerational epigenetic inheritance in multicellular organisms and discuss how alterations of the epigenotype might contribute to the determination of the adult phenotype of future generations. In particular, recent advances in our ability to study the integrity of the genome will help to identify true epigenetic phenomena.

\section{Naturally occurring epialleles}

Some of the earliest evidence for transgenerational epigenetic inheritance came from studies in plants (Bender and Fink 1995;

\footnotetext{
${ }^{1}$ Corresponding author.

E-mail emma.whitelaw@qimr.edu.au.

Article published online before print. Article and publication date are at http://www.genome.org/cgi/doi/10.1101/gr.106138.110.
}

Jacobsen and Meyerowitz 1997; Soppe et al. 2000; Rangwala et al. 2006). One of the oldest examples involves a change in flower symmetry from bilateral to radial in Linaria vulgaris. This change appears to be explained by a change in DNA methylation rather than DNA sequence. The phenotype of the flower correlates tightly with the degree of DNA methylation at the promoter of the Lcyc gene, and the presence or absence of DNA methylation at the promoter correlates with its silent or active state, respectively. Occasionally, reversions to wild-type flowers occur in one branch of a plant, concomitant with hypomethylation at the locus (Cubas et al. 1999). Sequencing of around $1 \mathrm{~kb}$ upstream of the $L c y c$ locus did not detect any differences between wild-type and mutant plants (Cubas et al. 1999). It is still not clear how the silent state is maintained across generations at the locus. It is important to note that care has to be taken when meiotically heritable changes in phenotype are described as epigenetic, because in most systems it is almost impossible to completely rule out mutations either at the locus or elsewhere in the genome that could contribute directly or indirectly to the phenotype. Only recently it was shown that the bal variant in Arabidopsis, which was long thought to have an underlying epigenetic explanation, arose from a gene duplication, and that the duplication alone is necessary and sufficient for the phenotype observed in the bal variant (Yi and Richards 2009). Duplicated regions of genomes are difficult to detect and therefore difficult to rule out.

It was shown recently that altered patterns of DNA methylation in plants (as seen in $d d m 1$ or met 1 mutants) can be heritable over many generations, even following backcrossing to wild-type plants (Johannes et al. 2009; Reinders et al. 2009). However, at some specific loci this is not the case; the methylation state reverts to that of the wild-type state. The reason for these differences is not clear.

The best evidence for transgenerational epigenetic inheritance in the mouse comes from the study of epialleles, such as agouti viable yellow and axin fused, in which DNA methylation levels of intracisternal A particle (IAP) retrotransposons control the expression of the neighboring gene. Alleles of this type are referred to as epialleles because the epigenetic state of the IAP transcriptional control element determines the phenotype. IAP elements are among a small group of long terminal repeat (LTR) retrotransposons, and it is interesting that this group appears to be resistant to the erasure of DNA methylation during reprogramming events in the gametes and early embryos (Morgan et al. 1999; Lane et al. 2003; Rakyan et al. 2003; Popp et al. 2010). Variable phenotypes 
(a range of coat colors from yellow, yellow and brown patches, to brown) are observed in inbred (and, therefore, presumably isogenic) mice carrying an agouti viable yellow allele, and this correlates with the DNA methylation status of the IAP. The epigenetic state can be transmitted to the next generation, maternally for agouti viable yellow and both maternally and paternally for axinfused (Morgan et al. 1999; Rakyan and Whitelaw 2003; Rakyan et al. 2003; Blewitt et al. 2006). Although the $A^{v y}$ and the axin-fused loci are the best-characterized epialleles in the mouse, the epigenetic marks that facilitate transgenerational epigenetic inheritance are not known. The simplest explanation has always been that DNA methylation at the locus escapes the reprogramming events. However, at least one study has shown that in blastocysts, following maternal transmission, DNA methylation at $A^{v y}$ is completely lost, suggesting that DNA methylation is not the inherited mark (Blewitt et al. 2006).

\section{Transgenerational epigenetic inheritance at transgenes}

There has been a long history of reports of epigenetic silencing at transgenes both in animals and plants (Hadchouel et al. 1987; Allen et al. 1990; Dorn et al. 1993; Kearns et al. 2000; Matzke et al. 2000; Sutherland et al. 2000; Lane et al. 2003; Xing et al. 2007). In some cases these silent states have been shown to be passed on to the next generation. For example, a transgene construct, consisting of polycomb response element (PRE), Fab-7, placed upstream of a GAL4 UAS-inducible reporter gene, provided the first evidence for transgenerational epigenetic inheritance in Drosophila (Cavalli and Paro 1998, 1999). During embryogenesis the normally silent state of the Fab7-PRE could be switched to active. This active state was stably maintained through many rounds of mitosis, but also through meiosis in the absence of the initial GAL4 inducer (Paro et al. 1998; Cavalli and Paro 1999).

A recent study in Arabidopsis has shown that after extreme temperature or UV-B stress, a silent transgene and some endogenous transposable elements were activated, and these changes were heritable for two generations. Interestingly, the loss of silencing at these loci correlated with an increase in histone acetylation, a mark known to be associated with active transcription, but was not accompanied by a loss of DNA methylation (Lang-Mladek et al. 2010). However, the changes in histone acetylation may well be a response to the change in transcriptional activity rather than a driver.

The molecular basis for the meiotic memory in both of these cases of transgenerational epigenetic inheritance at transgenes remains unknown.

\section{Paramutation}

Paramutation and paramutation-like phenomena have been described in plants, fungi, and mammals, and most extensively studied in maize. Paramutation involves an allelic interaction (in trans) that leads to a heritable change in gene expression. At the $b 1$ locus the "paramutagenic" $B^{\prime}$ allele (normally associated with pale plants) changes the epigenetic state of the "paramutable" B-I allele (normally associated with dark plants) when crossed, which results in a phenotypic change at the $B-I$ allele from dark purple to lightly pigmented mature plant tissues. No changes from $B^{\prime}$ to $B$-I have been observed, making the $B^{\prime}$ allele extremely stable over many generations (Arteaga-Vazquez and Chandler 2010). While the presence of tandem repeats in cis has been shown to play an important role in the $b 1$ paramutation system, the molecular basis of these phenomena has been has been difficult to understand (Stam et al. 2002).
Exciting results have been obtained recently from forward genetic screens using the $b 1$ locus and another paramutable locus, $p l 1$, and several genes required for paramutation have been uncovered (Dorweiler et al. 2000; Alleman et al. 2006; Erhard et al. 2009; Sidorenko et al. 2009; Stonaker et al. 2009). To date, the majority of the genes identified overlap with factors required for small RNA-mediated silencing (Arteaga-Vazquez and Chandler 2010). An RNA-dependent RNA polymerase has been shown to be absolutely required for the establishment and maintenance of paramutation (Alleman et al. 2006; Sidorenko and Chandler 2008).

A paramutation-like phenomenon has also been observed in the mouse. This involves the inheritance of a white-tail phenotype caused by an insertional mutation (a transgene was inserted downstream from the Kit promoter that produces an aberrant transcript) at the Kit locus, resulting in no KIT protein. Upon analysis of the offspring of heterozygous intercrosses (i.e., when breeding mice heterozygous for this mutant Kit allele) the number of phenotypically wild-type mice was less than that expected by Mendelian rules. Further analysis revealed that wild-type offspring were generated in the expected Mendelian ratio, but that most had maintained the mutant phenotype, displaying white tail tips. Importantly, this mutant phenotype (Kit*) could be transmitted by the genotypically wild-type mice to the next generation (Rassoulzadegan et al. 2006). A role for RNA in this paramutationlike phenomenon was proposed because elevated RNA levels were found in the sperm of mice heterozygous for the Kit mutation and in Kit* wild-type males. Paramutation could be induced following microinjection of microRNAs targeted to the Kit locus (Rassoulzadegan et al. 2006). However, concerns have been raised regarding the particular phenotype. The white tail is found surprisingly frequently in inbred C57BL/6 mice obtained from the Jackson Lab, i.e., those that we can be confident did not have ancestors carrying the Kit ${ }^{\text {tmlalf }}$ allele (Arnheiter 2007). Similar paramutation-like phenomena have been reported by the same group at some other loci in the mouse (Wagner et al. 2008; Grandjean et al. 2009).

In the case of paramutation in the mouse, it seems that the amount of RNA, originally present to trigger the response, is important for the transgenerational inheritance of the phenotype (Grandjean et al. 2009). A similar observation was described in C. elegans, where it was shown that heritable silencing of the oocyte maturation factor (oma-1) following dsRNA injection is dose dependent (Alcazar et al. 2008). Long-term silencing effects lasted three to four generations, but dropped significantly afterward. This transgenerational silencing has also been described with other target genes (Grishok et al. 2000; Vastenhouw et al. 2006). While molecular mechanisms for this transgenerational silencing in worms remain unknown, it has been shown that the silencing can be transmitted independently of the originally targeted locus, indicating a mobile silencing signal (Grishok et al. 2000; Alcazar et al. 2008). Alcazar and colleagues propose that RNA molecules are the inherited signal (Alcazar et al. 2008).

\section{Epigenetics and environment}

Throughout their life cycle, organisms are constantly exposed to environmental influences that pose a threat to the stability of their genome and/or epigenome. Several cases have been reported in various organisms, in which environmental influences such as exposure to chemicals (Anway et al. 2005; Vandegehuchte et al. 2009), nutritional supplements/nutrient availability (Wolff et al. 1998; Cooney et al. 2002; Dolinoy et al. 2006; Kaminen-Ahola 
et al. 2010), maternal behavior (Weaver et al. 2004), pathogens (Boyko et al. 2007), or temperature (Lang-Mladek et al. 2010) cause alterations in gene expression that persist throughout life and sometimes appear to be transmitted to the next generation.

Honeybees provide an interesting example of where a change in nutritional input dramatically alters the phenotype of the developing, genetically identical larvae. In the wild, larvae fed with royal jelly become queens, which differ significantly in their physiology from that of workers. It has been shown recently that downregulation of the bee's DNA methyltransferase, during a critical "decision-making" period in larval development, results in the emergence of an increased number of queens from the larvae not fed royal jelly (Kucharski et al. 2008). These studies highlight the importance of DNA methylation as an intermediary between the environment and the developmental outcomes.

A recent study in the mouse reported that ethanol consumption by pregnant females can influence the adult phenotype of the developing embryos. Developmental abnormalities (decrease in body weight, smaller skull size, and differences in cranial shape) were observed in adolescent offspring from mothers that were exposed to ethanol during the first half of pregnancy (Kaminen-Ahola et al. 2010). Moreover, using the epigenetically sensitive agouti viable yellow $\left(A^{v y}\right)$ as a read-out system, it was shown that ethanol exposure led to an increase in transcriptional silencing associated with hypermethylation at the $A^{v y}$ locus and a shift toward pseudoagouti (brown) (Kaminen-Ahola et al. 2010). It remains to be determined whether the effects observed after ethanol exposure can be transmitted to the next generations or are restricted to directly exposed animals. It is important to remember that when transgenerational phenomena are observed in mice that have been exposed to environmental stresses during pregnancy, not only the mother, but the $\mathrm{F}_{1}$ generation (embryo) and the developing germ line of the $\mathrm{F}_{2}$ generation are also exposed to these triggers (Youngson and Whitelaw 2008).

Another instance in which the $A^{v y}$ allele has been used as a biosensor revealed a shift of coat color toward pseudoagouti after feeding the mice a methyl-rich diet (Wolff et al. 1998; Cooney et al. 2002; Waterland and Jirtle 2003; Cropley et al. 2006, 2007; Waterland et al. 2006, 2007). DNA methylation at the $A^{v y}$ locus was found to be increased in animals that were fed with a methyl-rich diet (Waterland and Jirtle 2003). Follow-up studies were performed to determine whether increased DNA methylation levels at $A^{v y}$ were inherited to the next generation. Waterland et al. (2007) came to the conclusion that the acquired DNA methylation marks were not transgenerationally inherited, whereas using a slightly different breeding strategy, Cropley et al. (2006) reported the opposite.

An epigenetic memory of stress has been observed in dandelions (Taraxacum officinale) (Verhoeven et al. 2010). Dandelions are apomictic, i.e., they reproduce through unfertilized seeds, and are therefore assumed to be genetically identical, providing the opportunity of studying epigenetic variation in the absence of genotypic variation. In a recent study, isogenic dandelions were exposed to a variety of stresses (biotic and abiotic) and, together with the first generation of unstressed offspring, were analyzed for genome-wide DNA methylation changes using methylationsensitive amplified-fragment-length polymorphism. The results showed that stress-induced DNA methylation changes occurred, and that these changes were transmitted to the next generation (Verhoeven et al. 2010). The nature of the differentially methylated loci, i.e., whether they are genes or transposable elements, is not yet clear. Moreover, in the absence of a complete genome se- quence it is hard to rule out underlying genetic changes. Despite the technical challenges in studying dandelions, they provide an interesting example of a situation in which genetic variation is limited and where transgenerational epigenetic inheritance could provide a useful mechanism for adaptation to environmental changes.

Whereas inbred mouse strains and apomictic dandelions provide an opportunity to study epigenetic variation in a situation in which genetic variation is greatly mimimized, the situation is different in outbred populations, such as humans. Studies in monozygotic (MZ) twin pairs, which are genetically identical, provide some evidence for epigenetic variation between individuals within a twin pair (Fraga et al. 2005; Mill et al. 2006; Oates et al. 2006; Kaminsky et al. 2009). However, a more recent genome-wide study of the genetic, epigenetic, and transcriptomic differences in monozygotic twins discordant for multiple sclerosis failed to find any significant genetic or epigenetic differences (Baranzini et al. 2010). Clearly, more work needs to be carried out in this area. MZ twins provide a unique opportunity to unravel the extent to which the epigenome is hard-wired in humans.

The effects of environmental influences and the possibility that the resulting epigenetic alterations are heritable to the next generation are of considerable interest to those studying disease in humans. A recent study investigated the long-term effects of prenatal exposure to famine on DNA methylation at the imprinted IGF2 gene. Individuals conceived during the Dutch Hunger Winter (1944-1945) showed hypomethylation at the IGF2 differentially methylated region (DMR) when analyzed six decades later. Interestingly, no differences in DNA methylation were observed in individuals exposed to famine late in gestation. The finding suggests that the protein-deficient diet of the mother contributed to the loss of DNA methylation at the IGF2 DMR (Heijmans et al. 2008). It is difficult to tease out cause and effect. The loss of methylation in old age may be a consequence of some as yet unknown physiological changes. Unfortunately, in this study there is no record of DNA methylation patterns earlier in development. A prospective cohort study would be best, and epidemiologists are now collecting biospecimens from MZ twins at birth (Foley et al. 2009). This will provide us with exciting new data in the coming decades.

A large epidemiological study carried out in Sweden reported that early paternal smoking was associated with a greater body mass index in sons (Pembrey et al. 2006). Additionally, they found a correlation between mortality risk ratio of grandsons and paternal grandfather's food supply in mid-childhood. The mortality risk ratio of the granddaughters was linked to the paternal grandmother's food supply (Pembrey et al. 2006). While it is possible to explain these observations based on transgenerational epigenetic inheritance, other equally plausible explanations exist. In these types of studies, cultural confounders are almost impossible to rule out.

An epimutation in humans has been described in an individual with hereditary nonpolyposis colorectal cancer. The patient had altered DNA methylation patterns at one allele of MLH1, a DNA mismatch repair gene. Silencing of the MLH1 allele was detectable in all three germ layers, suggesting that an epimutation had occurred in the parental germ line. Some siblings inherited the same allele in an unmethylated state, and no DNA mutations were identified in the MLH1 coding or promoter regions, supporting the idea that this was a case of transgenerational epigenetic inheritance (Hitchins et al. 2005). However, a mechanism for the MLH1 epimutation has yet to be identified, and trans-acting genetic alterations cannot be ruled out (Hesson et al. 2010). There is 
increasing evidence that trans-effects can influence the epigenetic state of a locus so that undetected copy number variations, large duplications, and inversions anywhere in the genome could be the cause of the effect (Hesson et al. 2010).

\section{Toward a molecular mechanism}

In those cases in which transgenerational epigenetic inheritance has been observed, the underlying molecular mechanisms are poorly understood. The recent discovery that germ-line cells contain large numbers of different small RNA species in mice, flies, and plants suggests a novel way of transmitting epigenetic information through the germ line (Aravin and Hannon 2008; Mosher et al. 2009; Slotkin et al. 2009; Teixeira et al. 2009). Indeed, maternal transmission of Piwi-interacting RNAs (piRNAs) in Drosophila has been shown to influence fertility of the offspring via piRNA-directed silencing of transposable elements in a phenomenon termed hybrid dysgenesis (Brennecke et al. 2008). In mammals, microRNAs have been implicated as the trigger for a paramutation-like phenomenon, and this has been discussed above. However, the involvement of other classes of small RNAs in transgenerational epigenetic inheritance in mammals remains to be determined.

As we have indicated already, transgenerational epigenetic inheritance does appear to preferentially occur at transgenes, transposable elements, or genes that are under the transcriptional control of transposable elements. It has been suggested that what makes these states special is that they involve insertions, which, when heterozygous, trigger events such as "meiotic silencing of unpaired DNA" (MSUD), a process that has been extensively studied in Neurospora (Shiu et al. 2001).

Until recently, a role for chromatin in transgenerational epigenetic inheritance in mammals was considered unlikely, because in sperm the histones are replaced by smaller, arginine-rich protamines. This replacement would erase any epigenetic modification at histone tails, thereby preventing epigenetic inheritance. However, it has now become clear that some nucleosomes are retained, and these are not random remnants of insufficient clearance of epigenetic marks, but enriched at specific loci important for embryonic development. High levels of H3K27me3, H3K4me2, and H3K4me3 are found at these loci (Hammoud et al. 2009a,b; Brykczynska et al. 2010). Brykczynska et al. (2010) propose that H3K27me3 might be the epigenetic modification that is transmitted paternally to the next generation.

While the mechanisms of inheritance of histone modifications in mammals are still under debate, there is at least one report in C. elegans demonstrating the importance of complete erasure of $\mathrm{H} 3 \mathrm{~K} 4 \mathrm{me} 2$ patterns in the germ line to prevent transmission of this epigenetic mark to the next generation (Katz et al. 2009). The absence of the H3K4me2 demethylase LSD1/KDM1 in C. elegans over many generations was shown to result in a significant increase of H3K4me2 levels at genes required for spermatogenesis. The accumulation of active marks was shown to correlate with an increase in gene expression at these loci (Katz et al. 2009).

It has also been shown that haploinsufficiency for DNMT1 (a DNA methyltransferase) and SNF2H (SMARCA5) (a chromatin remodeler) in male mice can trigger phenotypic abnormalities in the offspring that did not inherit the mutated gene (Chong et al. 2007). These are referred to as paternal effects. Chong and colleagues proposed a model whereby a shift in dosage (or the compromised function) of epigenetic modifiers can modify the epigenome of wild-type gametes at regions that are not cleared, and that these can, in turn, act in trans on alleles introduced only via the egg. It will be interesting to see whether haploinsufficiency for other proteins involved in epigenetic reprogramming display similar effects.

\section{Conclusion and future directions}

Multicellular organisms have evolved complex mechanisms to clear epigenetic states between generations. However, in some cases these mechanisms can be circumvented. Recent studies across a wide range of species have strengthened the idea that the direct inheritance of RNA molecules and of chromatin states does occur, making these plausible explanations. The development of highthroughput methods of sequencing both RNA and DNA in combination with antibodies specific to particular histone modifications will enable us to fully characterize the epigenetic marks across the entire genome of gametes and early embryos in the near future. Together, these studies will provide us with exciting new insights on how and to what extent transgenerational epigenetic inheritance occurs in various organisms. Certainly, we are only at the beginning, and most likely we will have to revise our current models about the nature and stability of the epigenetic marks to fully understand this mechanism.

\section{Acknowledgments}

L.D. is supported by the Austrian Science Fund (FWF) Erwin Schroedinger Fellowship (J-2891-B12). E.W. is a National Health and Medical Research Council (NHMRC) Australia Fellow.

\section{References}

Alcazar RM, Lin R, Fire AZ. 2008. Transmission dynamics of heritable silencing induced by double-stranded RNA in Caenorhabditis elegans. Genetics 180: 1275-1288.

Alleman M, Sidorenko L, McGinnis K, Seshadri V, Dorweiler JE, White J, Sikkink K, Chandler VL. 2006. An RNA-dependent RNA polymerase is required for paramutation in maize. Nature 442: 295-298.

Allen ND, Norris ML, Surani MA. 1990. Epigenetic control of transgene expression and imprinting by genotype-specific modifiers. Cell 61: 853861.

Anway MD, Cupp AS, Uzumcu M, Skinner MK. 2005. Epigenetic transgenerational actions of endocrine disruptors and male fertility. Science 308: 1466-1469.

Aravin AA, Hannon GJ. 2008. Small RNA silencing pathways in germ and stem cells. Cold Spring Harb Symp Quant Biol 73: 283-290.

Arnheiter H. 2007. Mammalian paramutation: A tail's tale? Pigment Cell Res 20: $36-40$.

Arteaga-Vazquez MA, Chandler VL. 2010. Paramutation in maize: RNA mediated trans-generational gene silencing. Curr Opin Genet Dev 20: $156-163$.

Baranzini SE, Mudge J, van Velkinburgh JC, Khankhanian P, Khrebtukova I, Miller NA, Zhang L, Farmer AD, Bell CJ, Kim RW, et al. 2010. Genome, epigenome and RNA sequences of monozygotic twins discordant for multiple sclerosis. Nature 464: 1351-1356.

Bender J, Fink GR. 1995. Epigenetic control of an endogenous gene family is revealed by a novel blue fluorescent mutant of Arabidopsis. Cell 83: $725-734$.

Bird A. 2007. Perceptions of epigenetics. Nature 447: 396-398.

Blewitt ME, Vickaryous NK, Paldi A, Koseki H, Whitelaw E. 2006. Dynamic reprogramming of DNA methylation at an epigenetically sensitive allele in mice. PLoS Genet 2: e49. doi: 10.1371/journal.pgen.0020049.

Boyko A, Kathiria P, Zemp FJ, Yao Y, Pogribny I, Kovalchuk I. 2007. Transgenerational changes in the genome stability and methylation in pathogen-infected plants (virus-induced plant genome instability). Nucleic Acids Res 35: 1714-1725.

Brennecke J, Malone CD, Aravin AA, Sachidanandam R, Stark A, Hannon GJ. 2008. An epigenetic role for maternally inherited piRNAs in transposon silencing. Science 322: 1387-1392.

Brykczynska U, Hisano M, Erkek S, Ramos L, Oakeley EJ, Roloff TC, Beisel C, Schubeler D, Stadler MB, Peters AH. 2010. Repressive and active histone methylation mark distinct promoters in human and mouse spermatozoa. Nat Struct Mol Biol 17: 679-687. 
Cavalli G, Paro R. 1998. The Drosophila Fab-7 chromosomal element conveys epigenetic inheritance during mitosis and meiosis. Cell 93: $505-518$.

Cavalli G, Paro R. 1999. Epigenetic inheritance of active chromatin after removal of the main transactivator. Science 286: 955-958.

Chong S, Vickaryous N, Ashe A, Zamudio N, Youngson N, Hemley S, Stopka T, Skoultchi A, Matthews J, Scott HS, et al. 2007. Modifiers of epigenetic reprogramming show paternal effects in the mouse. Nat Genet 39: 614622 .

Cooney CA, Dave AA, Wolff GL. 2002. Maternal methyl supplements in mice affect epigenetic variation and DNA methylation of offspring. J Nutr 132: 2393S-2400S.

Cropley JE, Suter CM, Beckman KB, Martin DI. 2006. Germ-line epigenetic modification of the murine A vy allele by nutritional supplementation. Proc Natl Acad Sci 103: 17308-17312.

Cropley JE, Suter CM, Martin DI. 2007. Methyl donors change the germline epigenetic state of the $A^{v y}$ allele. FASEB J 21: 3021-3022.

Cubas P, Vincent C, Coen E. 1999. An epigenetic mutation responsible for natural variation in floral symmetry. Nature 401: 157-161.

Dolinoy DC, Weidman JR, Waterland RA, Jirtle RL. 2006. Maternal genistein alters coat color and protects Avy mouse offspring from obesity by modifying the fetal epigenome. Environ Health Perspect 114: 567-572.

Dorn R, Krauss V, Reuter G, Saumweber H. 1993. The enhancer of positioneffect variegation of Drosophila, E(var)3-93D, codes for a chromatin protein containing a conserved domain common to several transcriptional regulators. Proc Natl Acad Sci 90: 11376-11380.

Dorweiler JE, Carey CC, Kubo KM, Hollick JB, Kermicle JL, Chandler VL. 2000. mediator of paramutation1 is required for establishment and maintenance of paramutation at multiple maize loci. Plant Cell 12: 2101-2118.

Erhard KF Jr, Stonaker JL, Parkinson SE, Lim JP, Hale CJ, Hollick JB. 2009. RNA polymerase IV functions in paramutation in Zea mays. Science 323: 1201-1205.

Foley DL, Craig JM, Morley R, Olsson CA, Dwyer T, Smith K, Saffery R. 2009. Prospects for epigenetic epidemiology. Am J Epidemiol 169: 389-400.

Fraga MF, Ballestar E, Paz MF, Ropero S, Setien F, Ballestar ML, Heine-Suner D, Cigudosa JC, Urioste M, Benitez J, et al. 2005. Epigenetic differences arise during the lifetime of monozygotic twins. Proc Natl Acad Sci 102: 10604 10609.

Grandjean V, Gounon P, Wagner N, Martin L, Wagner KD, Bernex F, Cuzin F, Rassoulzadegan M. 2009. The miR-124-Sox9 paramutation: RNAmediated epigenetic control of embryonic and adult growth. Development 136: 3647-3655.

Grishok A, Tabara H, Mello CC. 2000. Genetic requirements for inheritance of RNAi in C. elegans. Science 287: 2494-2497.

Hadchouel M, Farza H, Simon D, Tiollais P, Pourcel C. 1987. Maternal inhibition of hepatitis B surface antigen gene expression in transgenic mice correlates with de novo methylation. Nature 329: 454-456.

Hammoud S, Emery BR, Dunn D, Weiss RB, Carrell DT. 2009a. Sequence alterations in the YBX2 gene are associated with male factor infertility. Fertil Steril 91: 1090-1095.

Hammoud SS, Nix DA, Zhang H, Purwar J, Carrell DT, Cairns BR. 2009b. Distinctive chromatin in human sperm packages genes for embryo development. Nature 460: 473-478.

Heijmans BT, Tobi EW, Stein AD, Putter H, Blauw GJ, Susser ES, Slagboom PE, Lumey LH. 2008. Persistent epigenetic differences associated with prenatal exposure to famine in humans. Proc Natl Acad Sci 105: 1704617049.

Henikoff S. 1990. Position-effect variegation after 60 years. Trends Genet 6: $422-426$

Hesson LB, Hitchins MP, Ward RL. 2010. Epimutations and cancer predisposition: Importance and mechanisms. Curr Opin Genet Dev 20: 290-298.

Hitchins M, Williams R, Cheong K, Halani N, Lin VA, Packham D, Ku S, Buckle A, Hawkins N, Burn J, et al. 2005. MLH1 germline epimutations as a factor in hereditary nonpolyposis colorectal cancer. Gastroenterology 129: $1392-1399$

Jacobsen SE, Meyerowitz EM. 1997. Hypermethylated SUPERMAN epigenetic alleles in Arabidopsis. Science 277: 1100-1103.

Johannes F, Porcher E, Teixeira FK, Saliba-Colombani V, Simon M, Agier N Bulski A, Albuisson J, Heredia F, Audigier P, et al. 2009. Assessing the impact of transgenerational epigenetic variation on complex traits. PLoS Genet 5: e1000530. doi: 10.1371/journal.pgen.1000530.

Kaminen-Ahola N, Ahola A, Maga M, Mallitt KA, Fahey P, Cox TC, Whitelaw E, Chong S. 2010. Maternal ethanol consumption alters the epigenotype and the phenotype of offspring in a mouse model. PLoS Genet 6: e1000811. 10.1371/journal.pgen.1000811.

Kaminsky ZA, Tang T, Wang SC, Ptak C, Oh GH, Wong AH, Feldcamp LA Virtanen C, Halfvarson J, Tysk C, et al. 2009. DNA methylation profiles in monozygotic and dizygotic twins. Nat Genet 41: 240-245.
Katz DJ, Edwards TM, Reinke V, Kelly WG. 2009. A C. elegans LSD1 demethylase contributes to germline immortality by reprogramming epigenetic memory. Cell 137: 308-320.

Kearns M, Preis J, McDonald M, Morris C, Whitelaw E. 2000. Complex patterns of inheritance of an imprinted murine transgene sugges incomplete germline erasure. Nucleic Acids Res 28: 3301-3309.

Kouzarides T. 2007. Chromatin modifications and their function. Cell 128: 693-705.

Kucharski R, Maleszka J, Foret S, Maleszka R. 2008. Nutritional control of reproductive status in honeybees via DNA methylation. Science 319: 1827-1830.

Lane N, Dean W, Erhardt S, Hajkova P, Surani A, Walter J, Reik W. 2003. Resistance of IAPs to methylation reprogramming may provide a mechanism for epigenetic inheritance in the mouse. Genesis 35: 88-93.

Lang-Mladek C, Popova O, Kiok K, Berlinger M, Rakic B, Aufsatz W, Jonak C, Hauser MT, Luschnig C. 2010. Transgenerational inheritance and resetting of stress-induced loss of epigenetic gene silencing in Arabidopsis. Mol Plant 3: 594-602.

Matzke MA, Mette MF, Matzke AJ. 2000. Transgene silencing by the host genome defense: Implications for the evolution of epigenetic contro mechanisms in plants and vertebrates. Plant Mol Biol 43: 401-415.

Mill J, Dempster E, Caspi A, Williams B, Moffitt T, Craig I. 2006. Evidence for monozygotic twin (MZ) discordance in methylation level at two CpG sites in the promoter region of the catechol-O-methyltransferase (COMT) gene. Am J Med Genet B Neuropsychiatr Genet 141B: 421-425.

Morgan HD, Sutherland HG, Martin DI, Whitelaw E. 1999. Epigenetic inheritance at the agouti locus in the mouse. Nat Genet 23: 314-318.

Mosher RA, Melnyk CW, Kelly KA, Dunn RM, Studholme DJ, Baulcombe DC. 2009. Uniparental expression of PolIV-dependent siRNAs in developing endosperm of Arabidopsis. Nature 460: 283-286.

Oates NA, van Vliet J, Duffy DL, Kroes HY, Martin NG, Boomsma DI, Campbell M, Coulthard MG, Whitelaw E, Chong S. 2006. Increased DNA methylation at the AXIN1 gene in a monozygotic twin from a pair discordant for a caudal duplication anomaly. Am J Hum Genet 79: 155-162.

Paro, R., Strutt, H., and Cavalli, G. 1998. Heritable chromatin states induced by the Polycomb and trithorax group genes. Novartis Found Symp 214: 51-61; discussion 61-56, 104-113.

Pembrey ME, Bygren LO, Kaati G, Edvinsson S, Northstone K, Sjostrom M, Golding J. 2006. Sex-specific, male-line transgenerational responses in humans. Eur J Hum Genet 14: 159-166.

Popp C, Dean W, Feng S, Cokus SJ, Andrews S, Pellegrini M, Jacobsen SE, Reik W. 2010. Genome-wide erasure of DNA methylation in mouse primordial germ cells is affected by AID deficiency. Nature 463: 1101-1105.

Rakyan V, Whitelaw E. 2003. Transgenerational epigenetic inheritance. Curr Biol 13: R6. 10.1016/S0960-9822(02)1377-5

Rakyan VK, Chong S, Champ ME, Cuthbert PC, Morgan HD, Luu KV, Whitelaw E. 2003. Transgenerational inheritance of epigenetic states at the murine Axin(Fu) allele occurs after maternal and paternal transmission. Proc Natl Acad Sci 100: 2538-2543.

Rangwala SH, Elumalai R, Vanier C, Ozkan H, Galbraith DW, Richards EJ. 2006. Meiotically stable natural epialleles of Sadhu, a novel Arabidopsis retroposon. PLoS Genet 2: e36. doi: 10.1371/journal.pgen.0020036.

Rassoulzadegan M, Grandjean V, Gounon P, Vincent S, Gillot I, Cuzin F. 2006. RNA-mediated non-mendelian inheritance of an epigenetic change in the mouse. Nature 441: 469-474.

Reinders J, Wulff BB, Mirouze M, Mari-Ordonez A, Dapp M, Rozhon W, Bucher E, Theiler G, Paszkowski J. 2009. Compromised stability of DNA methylation and transposon immobilization in mosaic Arabidopsis epigenomes. Genes Dev 23: 939-950.

Roemer I, Reik W, Dean W, Klose J. 1997. Epigenetic inheritance in the mouse. Curr Biol 7: 277-280.

Shiu PK, Raju NB, Zickler D, Metzenberg RL. 2001. Meiotic silencing by unpaired DNA. Cell 107: 905-916.

Sidorenko L, Chandler V. 2008. RNA-dependent RNA polymerase is required for enhancer-mediated transcriptional silencing associated with paramutation at the maize p1 gene. Genetics 180: 1983-1993.

Sidorenko L, Dorweiler JE, Cigan AM, Arteaga-Vazquez M, Vyas M, Kermicle J, Jurcin D, Brzeski J, Cai Y, Chandler VL. 2009. A dominant mutation in mediator of paramutation2, one of three second-largest subunits of a plant-specific RNA polymerase, disrupts multiple siRNA silencing processes. PLoS Genet 5: e1000725. doi: 10.1371/journal.pgen.1000725.

Slotkin RK, Vaughn M, Borges F, Tanurdzic M, Becker JD, Feijo JA, Martienssen RA. 2009. Epigenetic reprogramming and small RNA silencing of transposable elements in pollen. Cell 136: 461-472.

Soppe WJ, Jacobsen SE, Alonso-Blanco C, Jackson JP, Kakutani T, Koornneef M, Peeters AJ. 2000. The late flowering phenotype of fwa mutants is caused by gain-of-function epigenetic alleles of a homeodomain gene. Mol Cell 6: 791-802.

Stam M, Belele C, Dorweiler JE, Chandler VL. 2002. Differential chromatin structure within a tandem array $100 \mathrm{~kb}$ upstream of the maize $b 1$ locus is associated with paramutation. Genes Dev 16: 1906-1918. 
Stonaker JL, Lim JP, Erhard KF Jr, Hollick JB. 2009. Diversity of Pol IV function is defined by mutations at the maize rmr7 locus. PLoS Genet 5: e1000706. doi: 10.1371/journal.pgen.1000706.

Sutherland HG, Kearns M, Morgan HD, Headley AP, Morris C, Martin DI, Whitelaw E. 2000. Reactivation of heritably silenced gene expression in mice. Mamm Genome 11: 347-355.

Teixeira FK, Heredia F, Sarazin A, Roudier F, Boccara M, Ciaudo C, Cruaud C, Poulain J, Berdasco M, Fraga MF, et al. 2009. A role for RNAi in the selective correction of DNA methylation defects. Science 323: 1600-1604.

Vandegehuchte MB, Lemiere F, Vanhaecke L, Vanden Berghe W, Janssen CR. 2009. Direct and transgenerational impact on Daphnia magna of chemicals with a known effect on DNA methylation. Comp Biochem Physiol C Toxicol Pharmacol 151: 278-285.

Vastenhouw NL, Brunschwig K, Okihara KL, Muller F, Tijsterman M, Plasterk RH. 2006. Gene expression: Long-term gene silencing by RNAi. Nature 442: 882 . doi: $10.1038 / 442882 a$.

Verhoeven KJ, Jansen JJ, van Dijk PJ, Biere A. 2010. Stress-induced DNA methylation changes and their heritability in asexual dandelions. New Phytol 185: 1108-1118.

Waddington CH. 1942. The epigenotype. Endeavor 1: 10-20.

Wagner KD, Wagner N, Ghanbarian H, Grandjean V, Gounon P, Cuzin F, Rassoulzadegan M. 2008. RNA induction and inheritance of epigenetic cardiac hypertrophy in the mouse. Dev Cell 14: 962-969.
Waterland RA, Jirtle RL. 2003. Transposable elements: Targets for early nutritional effects on epigenetic gene regulation. Mol Cell Biol 23: 5293 5300 .

Waterland RA, Dolinoy DC, Lin JR, Smith CA, Shi X, Tahiliani KG. 2006. Maternal methyl supplements increase offspring DNA methylation at Axin Fused. Genesis 44: 401-406.

Waterland RA, Travisano M, Tahiliani KG. 2007. Diet-induced hypermethylation at agouti viable yellow is not inherited transgenerationally through the female. FASEB J 21: 3380-3385.

Weaver IC, Cervoni N, Champagne FA, D'Alessio AC, Sharma S, Seckl JR, Dymov S, Szyf M, Meaney MJ. 2004. Epigenetic programming by maternal behavior. Nat Neurosci 7: 847-854.

Wolff GL, Kodell RL, Moore SR, Cooney CA. 1998. Maternal epigenetics and methyl supplements affect agouti gene expression in Avy/a mice. FASEB J 12: 949-957.

Xing Y, Shi S, Le L, Lee CA, Silver-Morse L, Li WX. 2007. Evidence for transgenerational transmission of epigenetic tumor susceptibility in Drosophila. PLoS Genet 3: 1598-1606.

Yi H, Richards EJ. 2009. Gene duplication and hypermutation of the pathogen Resistance gene SNC1 in the Arabidopsis bal variant. Genetics 183: $1227-1234$.

Youngson NA, Whitelaw E. 2008. Transgenerational epigenetic effects. Annu Rev Genomics Hum Genet 9: 233-257. 


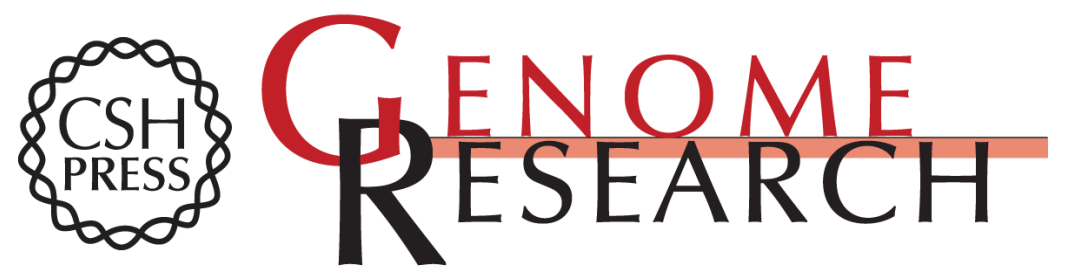

\section{Transgenerational epigenetic inheritance: More questions than answers}

Lucia Daxinger and Emma Whitelaw

Genome Res. 2010 20: 1623-1628 originally published online November 1, 2010

Access the most recent version at doi:10.1101/gr.106138.110

References This article cites 82 articles, 20 of which can be accessed free at:

http://genome.cshlp.org/content/20/12/1623.full.html\#ref-list-1

\section{License}

Email Alerting Receive free email alerts when new articles cite this article - sign up in the box at the Service top right corner of the article or click here.

\section{Affordable, Accurate Sequencing.}

To subscribe to Genome Research go to:

https://genome.cshlp.org/subscriptions 